\title{
An Econometric Model of the Role of Financial Institutions in Financing Private Investment in Pakistan
}

\begin{abstract}
ABUL M. M. MASIH*
The paper examines the relationship not only between private investment and financial linkage variables but also amongst the linkage variables. It examines the effect of different policy instruments on investment to provide guidelines to monetary authorities. It shows that the private investment in Pakistan was linked with the availability rather than the price of funds.
\end{abstract}

\section{INTRODUCTION}

The main objective of our study is to quantify the role of financial institutions $^{1}$ in financing private investment in Pakistan. In other words, we want to examine the relation between financial and real variables in the context of Pakistan. Most of the existing works in this field and the state of the present financial theory are vague in giving an objective and scientific method for evaluating the role of financial institutions in financing private investment. In view of the vague qualitative nature of most of the present works, we intended to apply an econometric method to find out this role.

The primary aims of the study are: (a) to examine the functional relations between private investment and financial variables, and (b) to examine the functional relations between those financial variables and the policy instruments of the monetary authorities. In other words, given the knowledge of the functional relations between private investment and transmission variables, such as interest rates, flow of

*The author is a Lecturer in Economics, University of New South Wales at Duntroon, Canberra, Australia. This paper is a revised version of a part of the author's $\mathrm{Ph}$. D. dissertation [20]. The author is deeply indebted to Mr. K. J. Woolmer and Professor C. E. V. Leser of the School of Economic Studies, University of Leeds, for their encouragement, guidance and helpful criticisms during the preparation stage of this dissertation. The author is also deeply grateful to Professor S. N. H. Naqvi, the Editor, and the anonymous referees of this journal for their helpful comments on earlier drafts of this paper. However, the author alone is responsible for any remaining errors.

${ }^{1}$ The term 'financial institutions' refers to both banks and non-bank institutions throughout the study. 
bank credit etc. (through which monetary changes make their impact on expenditures), on the one hand, and between those transmission variables and the policy instruments, on the other, in the framework of a simple econometric model, the monetary authorities could see (with the help of the 'reduced form' of the model) what instruments could be varied to affect the target variable - private investment in the plan period. It is in the context of this kind of model that we can better evaluate the role of financial institutions in financing private investment in Pakistan.

Our investigation tended to indicate that (a) private investment was linked by the availability, rather than the price, of funds since loan rate (like many other rates of interest) was controlled and set far below the equilibrium rate of interest, and (b) although the individual effect of some of the monetary policy instruments is clearly identifiable and positive on our target investment variable(s), the effect of a unit change of those policy variables on the increase in private investment (and hence on growth) appears to be very limited indeed from the point of view of practical policy significance. Our findings about the effects of disequilibrium interest rate setting appear to be consistent with the views of Shaw [25] and McKinnon [18] in regard to financial repression in economic development.

\section{METHODOLOGY AND SPECIFICATION OF THE MODEL - THE STRUCTURAL FORM}

The model consists of twelve endogenous variables and eleven pre-determined variables. The twelve endogenous variables are explained by eight behavioural relations and four identities. All equations are linearly independent. The number of observations for each variable is fifteen which covers the three five-year plans of Pakistan (1955-56 through 1969-70). The variables are in current prices ${ }^{2}$ and in million rupees, except the interest rate variables, which are in percentages. ${ }^{3}$ The structure of the model displays a considerable degree of "recursiveness" except the behavioural equations Nos. 4 and 5 which are interdependent and require to be estimated by simultaneous estimation methods such as T. S. L. S. method. It is not, therefore, very surprising that in our estimated model the O. L. S. and T. S. L. S. estimates of the parameters of the equations do not show any noticeable discrepancies.

The endogenous variables are:

${ }^{2}$ It might have been better if we could use constant prices, instead of current prices or both the prices but various price indices required for that conversion being either not available or highly suspect, we refrained from doing that.

${ }^{3}$ For the derivation and sources of the variables in detail, see Masih [20].
$\mathrm{CL}_{\mathrm{m}}^{\mathrm{L}}=$ Long-term loans and investments of all financial institutions (including scheduled banks ${ }^{4}$ ) to private large-scale manufacturing sector;

$\mathrm{CL}_{\mathrm{P}}^{\mathrm{L}}=$ Long-term loans and investments of all financial institutions (including scheduled banks) to the entire private sector;

$\mathrm{CL}^{\mathrm{LSCH}}=$ Long-term loans and investments of scheduled banks only to the private sector;

$\mathrm{CL}_{\mathrm{P}}=$ Total loans (both short-term and long-term) and investments of scheduled banks to the private sector;

D $=$ Total deposits (excluding inter-bank deposits) of the scheduled banks;

$\mathrm{D}^{\mathrm{D}}=$ Demand deposits (excluding inter-bank deposits) of the scheduled banks;

$\mathrm{D}^{\mathrm{T}}=$ Time deposits (excluding inter-bank deposits) of the scheduled banks;

$\mathrm{I}_{\mathrm{m}}^{\mathrm{F}} \quad=$ Gross private fixed investment expenditure (large-scale manufacturing sector only);

${ }_{\mathrm{P}}^{\mathrm{F}} \quad=$ Gross private fixed investment expenditure (whole private sector);

$\mathrm{R}^{\mathrm{B}}=$ Borrowings from the State $\cdot$ Bank of Pakistan ${ }^{5}$ by the scheduled banks;

$\mathrm{S}=$ Holdings of securities (mostly Government) by the scheduled banks; and

$\mathrm{SCL}^{\mathrm{G}}=$ Total of banks' ${ }^{6}$ holdings of securities (mostly Government) and loans to the Government.

The pre-determined variables are:
$\mathrm{CL}^{\mathrm{G}}=$ Loans to the Government by the banks;
DF = Deficit financing by the Government;
$\mathrm{D}_{1}=$ Dummy variable taking care of the change of Government in 1958-59;

\footnotetext{
${ }^{4}$ Legal title of commercial banks in Pakistan.

${ }^{5}$ Legal title of the Central Bank in Pakistan.

${ }^{6}$ The terms 'banks' and 'scheduled banks' are used interchangeably.
} 
$\mathrm{LA}_{-1}^{\mathrm{E}}=$ Excess liquid-asset holdings by banks (lagged);

$\mathrm{R}_{-1}^{\mathrm{B}} \quad=$ Borrowings of the banks (lagged) from the Central Bank;

$r^{G} \quad=$ Weighted average rate of interest on Government securities;

$\mathrm{r}^{\mathrm{T}} \quad=$ Weighted average rate of interest on time deposits;

SPE $=$ Loans and investments of specialised credit institutions, excluding the House Building Finance Corporation (HBFC);

SPE $^{\mathrm{HB}}=$ Loans and investments of specialised credit institutions including HBFC;

$\mathrm{X}_{\mathrm{t}-1}=$ Foreign exchange (lagged); and

$\mathrm{Y}=$ G. N.P. at current factor cost.

The following relationships are postulated:

\section{Identities}

1. Long-term loans and investments of all financial institutions to private largescale manufacturing sector:

$$
\Delta \mathrm{CL}_{\mathrm{m}}^{\mathrm{L}}=\Delta \mathrm{SPE}+\Delta \mathrm{CL}^{\mathrm{LSCH}}
$$

2. Long-term loans and investments of all financial institutions to the whole private sector:

$$
\Delta \mathrm{CL}_{\mathbf{P}}^{\mathrm{L}}=\Delta \mathrm{SPE}^{\mathrm{HB}}+\Delta \mathrm{CL}^{\mathrm{LSCH}}
$$

3. Banks' holdings of securities (mostly Government) and loans to Government:

$$
\Delta \mathrm{SCL}^{\mathrm{G}}=\Delta \mathrm{S}+\Delta \mathrm{CL}^{\mathrm{G}}
$$

4. Total deposits (non-bank):

$$
\Delta \mathrm{D}=\Delta \mathrm{D}^{\mathrm{D}}+\Delta \mathrm{D}^{\mathrm{T}}
$$

\section{Behavioural Equations}

1. Gross private fixed investment expenditure (large-scale manufacturing sector only):

$$
\mathrm{I}_{\mathrm{m}}^{\mathrm{F}}=\mathrm{a}_{1}+\mathrm{b}_{1} \Delta \mathrm{CL}_{\mathrm{m}}^{\mathrm{L}}+\mathrm{c}_{1} \mathrm{X}_{\mathrm{t}-1}+\mathrm{d}_{1} \mathrm{D}_{1}+\mu_{1}
$$

2. Gross private fixed investment expenditure (whole private sector):

$$
\mathbf{I}_{\mathbf{P}}^{\mathrm{F}}=\mathrm{a}_{2}+\mathrm{b}_{2} \Delta \mathrm{CL}_{\mathbf{P}}^{\mathrm{L}}+\mathrm{c}_{2} \mathrm{X}_{\mathrm{t}-1}+\mathrm{d}_{2} \mathrm{D}_{1}+\mu_{2}
$$

3. Banks' long-term loans and investments to private sector:

$$
\Delta \mathrm{CL}^{\mathrm{LSCH}}=\mathrm{a}_{3}+\mathrm{b}_{3} \Delta \mathrm{CL}_{\mathrm{P}}+\mu_{3}
$$

4. Supply of banks' total loans and investments to private sector:

$$
\Delta \mathrm{CL}_{\mathrm{P}}=\mathrm{a}_{4}+\mathrm{b}_{4} \quad \Delta \mathrm{D}+\mathrm{c}_{4} \quad \Delta \mathrm{R}^{\mathrm{B}}+\mathrm{d}_{4} \quad \Delta \mathrm{LA}_{-1}^{\mathrm{E}}+\mu_{4}
$$

5. Banks' borrowings from the State Bank of Pakistan:

$$
\Delta \mathrm{R}^{\mathrm{B}}=\mathrm{a}_{5}+\mathrm{b}_{5} \quad \Delta \mathrm{CL}_{\mathrm{P}}-\mathrm{c}_{5} \mathrm{R}_{-1}^{\mathrm{B}}+\mathrm{d}_{5} \Delta \mathrm{SCL}^{\mathrm{G}}+\mu_{5}
$$

6. Holdings of securities (mostly Government) by the banks:

$$
\Delta \mathrm{S}=\mathrm{a}_{6}+\mathrm{b}_{6} \mathrm{r}^{\mathrm{G}}-\mathrm{c}_{6} \Delta \mathrm{LA}_{-1}^{\mathrm{E}}+\mathrm{d}_{6} \mathrm{DF}+\mu_{6}
$$

7. Private demand for demand deposits (non-bank):

$$
\Delta \mathrm{D}^{\mathrm{D}}=\mathrm{a}_{7}+\mathrm{b}_{7} \quad \mathrm{Y}+\mu_{7}
$$

8. Private demand for time deposits (non-bank):

$$
\Delta \mathrm{D}^{\mathrm{T}}=\mathrm{a}_{8}+\mathrm{b}_{8} \mathrm{r}^{\mathrm{T}}+\mu_{8}
$$

Note: (i) $\Delta=$ Annual changes in the holdings of an asset by the banks or by the non-bank public.

(ii) a. b. c. $d^{\prime} s$ are constants and $\mu^{\prime}$ s are disturbances.

In the first and second behavioural relationships, given high marginal efficiency of investment and high demand for investible funds during the period Lnder review, it is hypothesized that private investment was constrained not by factors generating demand for investment but by the availability of funds as reflected in the two financing variables $\Delta \mathrm{CL}_{\mathrm{m}}^{\mathrm{L}}$ (or $\Delta \mathrm{CL}_{\mathrm{P}}^{\mathrm{L}}$ ) and $\mathrm{X}_{\mathrm{t}-1}$. The marginal efficiency of investment in a sheltered home market being very high relative to the controlled market rate of interest set at below-equilibrium level, the loan rate was not expected to be significant. $^{7} \quad$ A Dummy $\left(D_{1}\right)$ also deserves to be tested since it stands for the change of government in 1958-59 and the coming of a stable government with its all-out efforts for industrialization of the economy.

The third behavioural relationship simply postulates that banks' long-term loans to the private sector depend on their total loans $\left(\Delta \mathrm{CL}_{\mathbf{p}}\right)$.

In the fourth relationship, in line with our earlier supply-constraint hypothesis of private fixed investment function, we postulate that bank credit was constrained not by factors generating demand for it but by the availability of loanable funds

${ }^{7}$ This leads to the point that non-price rationing of investible funds must occur. This is based on the quality of collateral, political pressures, "name", loan size and covert benefits to the responsible loan officers. These criteria can be counted on to discriminate inefficiently between investment opportunities $[10$, p. 465$]$. 
given by the flow of new deposits $(\triangle D)$, borrowings from the central bank $\left(\triangle R^{B}\right)$ and the running down of excess liquid assets $\left(\Delta \mathrm{LA}_{-1}^{\mathrm{E}}\right)$. The loanable fund market being highly profitable, the price of the asset or its substitute was not postulated to be significant in the function. The banks' portfolio behaviour lends support to our above hypotheses.

The fifth relationship relates to the borrowing behaviour of the banks. Since the banks were being controlled and influenced by the big industrialist customers, banks could ill-afford, despite their tight liquidity position, to dishonour the wishes of those big regular customers. Hence the banks' borrowing from the central bank $\left(\triangle R^{B}\right)$ was likely to be sensitive to the demand for more loans from the existing customers $\left(\triangle C L_{\mathrm{P}}\right)$. Moreover, since the banks were already in heavy debt to the central bank in most of the years, they could not afford to have new borrowings without carefully considering their level of outstanding borrowings $\left(\mathrm{R}_{-1}^{\mathrm{B}}\right)$. And, finally, the banks' ability to produce government securities and counter-finance certificates for loans to the government $\left(\triangle S C L^{G}\right)$, both of which were undeniable collateral for borrowing from the central bank, is also expected to be a significant determinant.

The sixth relationship explains the security holdings of the banks $(\triangle S)$ which are mostly of the government origin. We postulate that unlike the loan rate and the bank rate, the weighted rate of interest in government securities $\left(\mathrm{r}^{\mathrm{G}}\right)$ will be a significant determinant of the changes in the holdings of government securities. A given rise in that rate will, to that extent, reduce the banks' opportunity cost of lending to the public. Moreover, faced with the liquidity constraint and various uncertainties, coupled with the factor that banks held an insignificant amount of non-earning excess cash reserves (which were generally lent to the profitable private sector), the banks could ill-afford to ignore any inducement to hold more government securities (which were as good as cash in the institutional set-up of Pakistan), mainly to serve their liquidity and security considerations. It is also postulated that changes in the holdings of securities (which are a part of the banks' liquid assets) are also likely to be sensitive to the excess liquid assets of the previous period $\left(\triangle \mathrm{LA} \mathrm{E}_{-1}\right)$. Finally, since the government financed the budget deficit mostly by borrowing from the banks, we postulate that the greater the need of the government to finance the budget deficit, the greater will be the pressure on the commercial banks to hold government securities, which were, however, made undeniable collateral for banks' borrowing from the central bank.

The seventh and eighth relationships explain the private sector demand for demand deposits and time deposits respectively. It is conjectured that, in the context of Pakistan, while demand deposits mainly serve the purpose of transaction motive, and transaction balances are most likely to be affected by the level of the G. N. P., the balances for precautionary motive (which is very important in view of the near-subsistence level of the vast majority of the people of Pakistan) are possibly taken care of by time deposits. Based on the works of Adekunle [2], Fan and Liu [9] and Mammen [19], which suggest that current income could be used as an approximation to permanent income in the LDCs, we postulate the GNP at current factor cost (Y) as the relevant constraint variable in the demand deposit function. In the case of the time deposit function, in line with our preceding argument, we hypothesize the weighted average rate of interest on time deposits $\left(\mathrm{r}^{\mathrm{T}}\right)$ as the relevant constraint variable.

\section{MODEL RESULTS AND EVALUATION OF THE STRUCTURAL EQUATIONS OF THE MODEL}

The structural model outlined in the previous section has been estimated for Pakistan. It covers the period from 1955-56 to 1969-70 and uses annual data. Estimates of the model are reported below:

Full Model $^{8}$ (a) OLS estimate (b) TSLS estimate.

Identities

\begin{tabular}{|c|c|c|c|c|}
\hline 1. $\Delta \mathrm{CL}_{\mathrm{m}}^{\mathrm{L}}$ & $=$ & $\triangle \mathrm{SPE}$ & + & $\Delta \mathrm{CL}^{\mathrm{LSCH}}$ \\
\hline 2. $\Delta \mathrm{CL}_{\mathrm{P}}^{\mathrm{L}}$ & $=$ & $\triangle \mathrm{SPE}^{\mathrm{HB}}$ & + & $\Delta \mathrm{CL}^{\mathrm{LSCH}}$ \\
\hline 3. $\triangle \mathrm{SCL}^{\mathrm{G}}$ & $=$ & $\Delta S$ & + & $\Delta \mathrm{CL}^{\mathrm{G}}$ \\
\hline 4. $\triangle \mathrm{D}$ & $=$ & $\Delta \mathrm{D}^{\mathrm{D}}$ & + & $\Delta \mathrm{D}^{\mathrm{T}}$ \\
\hline
\end{tabular}

Behavioural Equations

$$
\begin{aligned}
& \text { 1. (a) } \mathrm{I}_{\mathrm{m}}^{\mathrm{F}}=\underset{(134.398)}{97.841}+\underset{(0.283)}{0.737 \Delta \mathrm{CL}_{\mathrm{m}}^{\mathrm{L}}}+\underset{(0.039)}{0.113 \mathrm{X}_{\mathrm{t}-1}} \\
& 295.148 \quad \mathrm{D}_{1} \\
& \text { (141.412) } \\
& \mathrm{R}^{2}=90 \text { D.W. }=2.1 \\
& \text { (b) } \mathrm{I}_{\mathrm{m}}^{\mathrm{F}}=\underset{(141.003)}{89.958}+\underset{(0.303)}{0.696 \Delta \mathrm{CL}_{\mathrm{m}}^{\mathrm{L}}}+\underset{(0.041)}{0.116 \mathrm{X}_{\mathrm{t}-1}}+ \\
& 303.110 \mathrm{D}_{1} \\
& \text { (148.313) } \\
& \mathrm{R}^{2}=.89 \text { D. W. }=2.1
\end{aligned}
$$

${ }^{8}$ For the derivation (including specification and estimation) of the behavioural equations of the model, see Masih [20, Chapters VII, VIII and IX] 
2. (a) $\mathrm{I}_{\mathrm{P}}^{\mathrm{F}}=\begin{aligned} & -248.207 \\ & \begin{array}{l}(248.181) \\ \end{array}\end{aligned}$

(b) $\mathrm{I}_{\mathrm{P}}^{\mathrm{F}}=\underset{(253.947)}{-245.912}+\underset{(0.530)}{1.882 \Delta \mathrm{CL}_{\mathrm{P}}^{\mathrm{L}}}+\underset{(0.075)}{0.344 \mathrm{X}_{\mathrm{t}-1}}+$ $873.519 \mathrm{D}_{1}$

(269.614)

$$
\mathrm{R}^{2}=.96 \text { D.W. }=1.67
$$

3. (a) $\Delta \mathrm{CL}^{\mathrm{LSCH}}=\underset{(36.993)}{27.271}+\begin{gathered}0.116 \Delta \mathrm{CL}_{\mathrm{P}} \\ (0.042) \\ \mathrm{R}^{2}=.38 \text { D.W. }=1.88\end{gathered}$ (b) $\Delta \mathrm{CL}^{\mathrm{LSCH}}=\underset{(38.145)}{29.760}+\underset{(0.043)}{0.112 \Delta \mathrm{CL}_{\mathrm{P}}}$

$$
\mathrm{R}^{2}=.34 \text { D. W. }=1.86
$$

4. (a) $\Delta \mathrm{CL}_{\mathrm{P}}=-64.158+0.818 \Delta \mathrm{D}+0.826 \Delta \mathrm{R}^{\mathrm{B}}+$

$$
\begin{array}{lll}
(49.700) & (0.057) \quad(0.086)
\end{array}
$$$$
0.373 \Delta \mathrm{LA}_{\mathrm{t}-1}^{\mathrm{E}}
$$$$
\text { (0.124) }
$$

$$
\mathrm{R}^{2}=.98 \text { D. W. }=2.02
$$
(b) $\Delta \mathrm{CL}_{\mathrm{P}}=\underset{(65.226)}{65.799}+\underset{(0.075)}{0.819 \Delta \mathrm{D}}+\underset{(0.117)}{0.833 \Delta \mathrm{RB}}+$

$0.375 \Delta \mathrm{LA} \mathrm{t}_{\mathrm{t}-1}^{\mathrm{E}}$

(0.163)

$$
\mathrm{R}^{2}=.96 \text { D. W. }=3.0
$$

5. (a) $\Delta \mathrm{R}^{\mathrm{B}}=\underset{(56.955)}{-\underset{(0.061)}{170.219}}+\underset{(0.062)}{0.598 \Delta \mathrm{L}_{\mathrm{P}}}-\underset{\mathrm{t}-1}{0.499} \mathrm{R}^{\mathrm{B}}+$

$0.874 \triangle \mathrm{SCL}^{\mathrm{G}}$

(0.166)

$$
\mathrm{R}^{2}=.91 \text { D.W. }=1.95
$$

(b) $\Delta \mathrm{R}^{\mathrm{B}}=-170.084+0.595 \Delta \mathrm{CL}_{\mathrm{P}}-0.500 \mathrm{R}_{\mathrm{t}-1}^{\mathrm{B}}+$ $\begin{array}{lll}(72.614) \quad(0.078) & (0.079)\end{array}$

$0.886 \triangle \mathrm{SCL}^{\mathrm{G}}$

$(0.215)$$$
\mathrm{R}^{2}=.86 \quad \text { D.W. }=2.1
$$
6. (a) $\Delta \mathrm{S}=-437.454+159.089 \mathrm{r}^{\mathrm{G}}-0.244 \Delta \mathrm{LA}_{\mathrm{t}-1}^{\mathrm{E}}+$$$
(152.660) \quad(41.416) \quad(0.094)
$$
$0.135 \mathrm{DF}$
(0.063)

$$
\mathrm{R}^{2}=.72 \text { D. W. }=1.40
$$

(b) $\Delta \mathrm{S}=$ As in $6(\mathrm{a})$

7. (a) $\Delta \mathrm{D}^{\mathrm{D}}=\begin{aligned} & -98.143 \\ & (140.891)\end{aligned}$

(b) $\Delta \mathrm{D}^{\mathrm{D}}=\quad$ As in 7 (a)

8. (a) $\Delta \mathrm{D}^{\mathrm{T}}=-255.878+242.980 \mathrm{r}^{\mathrm{T}}$

(192.066) (63.082)

(b) $\Delta \mathrm{D}^{\mathrm{T}}=\quad$ As in 8 (a)

Evaluation of the Structural Equations of the Model

We start with the identities. All the identities have policy implications since they incorporate variables, either controlled or influenced by the government, such as flow of loans and investments of specialised credit institutions, either excluding House Building Finance Corporation ( $\triangle \mathrm{SPE})$ in identity (1) or including it $\left(\triangle \mathrm{SPE}{ }^{\mathrm{HB}}\right)$ in identity (2), advances to the government by the commercial banks $\left(\Delta C L^{G}\right)$ in identity (3). Finally, the breakup of the total deposits into demand deposits and time deposits in identity (4) was designed to analyse separately the determinants of these two components of total deposits. We can see later that the time deposit function does incorporate the important policy variable $\left(\mathrm{r}^{\mathrm{T}}\right)$ but the demand deposit function does not find it significant at all. Hence our breakup appears to be justified.

The Behavioural Relationships

A comparison between OLS and TSLS estimates shows little difference. Since the coefficients are very close, we could discuss them taking either of the estimates 
(OLS or TSLS) which will be valid for both. Equations 1 and 2 establish the significance of the two financing variables - the loan variable and the foreign exchange variable - in explaining investment expenditures in Pakistan. We must bear in mind, however, that the problem of multicollinearity did not allow us to bring together plausible variables like value added and gross profits in these equations. Elasticity computation indicates that the sensitiveness of investment with respect to foreign exchange variable is far greater than that with respect to the loan variable. Although elasticities of both variables - loan and foreign exchange - increased in the later period (for example, in equation 1, they were 0.30 and 0.56 respectively in 1968-69 compared to the mean elasticities of 0.19 and 0.49 respectively whereas in equation 2 , they were 0.33 and 0.64 respectively in 1968-69 compared to the mean elasticities of 0.23 and 0.60 respectively), but relatively the sensitiveness of investment to the foreign exchange variable was always higher. The significance of the loan variable in the investment function was also established by Avramides [5], Goldfeld [11], Cohen [8], Argy [3], Islam [15], Imam [14], and Gupta [12]. Finally, as expected, the dummy variable $\left(\mathrm{D}_{1}\right)$ taking care of the change of government did come out significant in both the investment functions.

In equation 3 , although $\mathrm{R}^{2}$ is low relative to other functions in our model, the ' $F$ ' test indicates that the correlation between the flow of long-term loans and the total flow of bank loans to the private sector is highly significant (though not strong). Elasticity computation shows that elasticity is 0.7 indicating that a one percent change in the flow of total loans leads to a 0.7 percent change in the flow of longterm loans. The increasing importance of the long-term loan variable is in line with the pressure put by big industrialists (who controlled the banks) for more long-term loans in the form of term loans etc. for fixed assets, given the favourable climate of investment and the increasing share of fixed assets in total assets $[22 ; 16]$. The pressure on banks for longer-term loans was greater because of the lack of alternative sources such as inadequate internal funds relative to the untapped profitable projects, underdeveloped stock market, and inadequate resources of the non-bank financial institutions [24]. The rise in the ratio of time deposits to total deposits and the refinance facility provided by the central bank against long-term capital financing by banks possibly facilitated the trend. According to one study [21, p. 234], about 25 percent of total loans (with increasing trend) of banks in Pakistan were in term lending and this growing importance of long-term loans gets reflected in the longterm loan function.

In the bank-credit supply function (equation 4), the relative importance of the three explanatory variables is reflected in their respective elasticities (which are 0.95 ,
0.11 and 0.02 for new deposits), borrowing from the central bank and excess liquid assets, respectively. An experiment with the bank-credit demand function performed rather poorly. Being resource-constrained, bank credit seems to be highly sensitive to change in deposits ${ }^{9}$ followed by their recourse to the central bank. The banks seem to fall back on their excess liquid assets as a last resort. ${ }^{10}$

In equation 5 , which relates to the borrowing behaviour of the banks, the adjustment coefficient of 0.50 indicates that the speed of adjustment was neither very fast nor slow and does not seem to be very far from reality. The relative importance of the three explanatory variables is reflected in their elasticities which are $4.1,3.5$ and 2.2 respectively. As expected, neither the bank rate nor the difference between the lending rate and the bank rate came out significant.

In equation 6 , the relative responsiveness (as measured by relative elasticities) of changes in banks' holdings of government securities with respect to the rate of interest on government securities, excess liquid assets of the previous year and government deficit financing was found to be $3.1,0.06$ and 2.6 respectively. The high sensitivity to the rate-of-interest variable ${ }^{11}$ is plausible since, apart from the theoretical reasonings advanced before, a rise in the yield will increase both banks' holdings of new issues of government securities and bank credit to the private sector by increasing the loanable funds of the banks. (For further explanation, please refer to our evaluation of the reduced form.) The least sensitivity to excess liquid assets of the previous year is in line with our earlier observation about its residual nature in banks' supply function for bank credit. The magnitude and elasticity of deficit financing variable reflect partly the pressure of the monetary authorities on the banks to hold some government securities and partly the economic considerations of the banks themselves.

Equations 7 and 8 refer to the demand deposit and time deposit functions. Our attempts to improve the explanations (since $\mathrm{R}^{2}$ is rather low in both equations) by adding'various other theoretically plausible variables and by $\log$ transformation of the variables did not bear fruit. The rate of interest did not come out significant in the demand deposit function and the rate of the change of prices was not significant

${ }^{9}$ The reader might recall that in Pakistan's conditions, the bank multiplier is very low, implying thereby a low ratio of credit expansion as a result of an increase in the cash base; or, in
other words, an increase of a million rupees in bank credit required an almost equal amount of cash deposits. Owing to high leakages and low multiplier in Pakistan, it was mostly the change in deposits that led to the change in bank credit rather than the other way round.

${ }^{10}$ This residual nature of the excess liquid assets is consistent with the banks' need for keeping some excess liquid assets for a smooth functioning of the banking system in Pakistan.

${ }^{11}$ Our findings of the significance of the weighted average rate of interest on government securities are consistent with the plea made by Porter [23] for raising the yields on government securities in Pakistan. 
in either function. ${ }^{12}$ High correlation among the GNP, lagged dependent variable and monetization, however, did not allow us to bring these variables together in the same equation. The elasticity of the flow of demand deposit with respect to the change in the GNP is 1.41 , quite in line with that evidenced in some other countries. The flow of time deposits seems to be quite sensitive to the change in its rate of interest (elasticity being 1.58). This is in line with the period under review since currency/GNP was falling rapidly, tempered slightly by a rising demand deposit/GNP but accompanied by a sharply rising time deposit/GNP. This is expected at the early stage of industrialization in an economy when after an initial period of rising currency/GNP, with the rise in banking habits and the knowledge of the opportunity cost of the rate of interest, people start depositing the transaction balance as demand deposits for liquidity considerations, and substantial precautionary balances (hitherto kept in the form of currency) start getting into the banks in the form of interestearning time deposits. This is consistent with the lack of substantial inflation in Pakistan during that period and with the growing confidence of people in the banking system under a relatively stable government. Our findings are broadly in line with the contentions of Niazi [21] about public demand for currency, demand deposits and time deposits in Pakistan. The high significance of the rate of interest in time deposit function is backed by findings in some other countries as well. ${ }^{13}$ See, for example, $[17$, p. 205], [4, p. 326], [13, p. 68], [26, p. 32], and [24, p. 95].

\section{SOME LIMITATIONS OF THE STUDY}

Firstly, one may have reservations about the econometric approach to economic research, particularly in financial field and more so with respect to the developing countries like Pakistan. It is still debatable whether, in financial research, the focus should be on descriptively accurate constructs or on quantitatively tractable constructs. The author's judgment of the broad merits of the debate are, of course, implicit in the nature of this work. However, what is worth stressing is that structural models are advocated here not to supplant but to supplement other approaches. Secondly, the results reported in the study are subject to the assumptions made such as linearity. Moreover, the estimates are in many cases subject to the problem of multicollinearity which we could not get rid of despite efforts. As a result, some of

${ }^{12}$ The rate of change of price variable has been tested in all the relevant behavioural equations of the model but nowhere has it been found significant at all. This is in line with the relative stability of the price level in Pakistan during most of the period under study. For other plausible explanations, readers are referred to Masih [20].

${ }^{13}$ For a varied experience of some Asian countries regarding the efficacy of interest rate policies in mobilising voluntary private financial savings, see Chandavarkar [6]. the explanatory variables retained in the final equations might have absorbed some of the effects of the collinear variables dropped. Hence, the importance of the collinear variables dropped should not be underestimated. All these, together with the limitations of data, particularly of investment, GNP etc., tend to suggest that the estimates should be viewed with caution if any policy recommendations are to follow from them. Finally, econometric models become rapidly obsolete as theory develops, new data become available and structural-institutional changes take place over time. Hence the need of periodic revisions of the model to keep its utility alive. In real life, many social and political pressures have to be accommodated and hence our parameters should be taken as broad orders of magnitude and our conclusions as tentative.

\section{THE REDUCED FORM OF THE MODEL AND POLICY IMPLICATIONS}

The derivation of the reduced form was a necessary step to ascertain which policy variables could have been manipulated by the monetary authorities to affect our target variable, viz. Private Investment. ${ }^{14}$

\section{Evaluation of the Reduced Form}

Reduced form discussion can take place in two forms: (a) looking at each column individually to examine the effects of a unit change in each of the predetermined variables on each endogenous variable in turn, and (b) looking at each row of the reduced form to examine the best combination of the predetermined variables in the sub-sets on the target variable, keeping in mind the side effects that the change in each predetermined variable will have on the other endogenous variables of the system. We shall discuss briefly the above two ways of reading the reduced form and examine how our target variable, private investment, is affected by the unit change in the policy variables.

\section{1}

Let us suppose that we want to examine how the unit change in the rate of interest on time deposits (i.e. $\mathrm{r}^{\mathrm{T}}$ ) affects our private manufacturing investment (i.e. $\mathrm{I}_{\mathrm{m}}^{\mathrm{F}}$ ) or total private sector investment (i.e. $\mathrm{I}_{\mathrm{P}}^{\mathrm{F}}$ ).

We can see that a one percent change in $\mathrm{r}^{\mathrm{T}}$ (rate of interest on Time Deposits) increases $\mathrm{I}_{\mathrm{m}}^{\mathrm{F}}$ by 30.7 million rupees. But this is the final effect on $\mathrm{I}_{\mathrm{m}}^{\mathrm{F}}$ from a unit

${ }^{14}$ The reader might recall that our policy variables are: $\triangle \mathrm{SPE}, \triangle \mathrm{SP}, \mathrm{E}^{\mathrm{HB}}, \mathrm{DF}, \triangle \mathrm{LA}{ }_{-1}^{\mathrm{E}}, \mathrm{r}^{\mathrm{G}}$, $\mathrm{r}^{\mathrm{T}}$, and $\Delta \mathrm{CL}^{\mathrm{G}}$. The reduced form has been presented in such a way that the fuil matrix can be partitioned and the policy sub-matrix $\underset{F}{c}$ be seen separately. Our target variables are the two private investment variables, which are $\mathrm{I}_{\mathrm{m}}^{\mathrm{F}}$ and $\mathrm{I}_{\mathrm{P}}^{\mathrm{F}}$. 
change in $r^{T}$. We can see from our structural system that $r^{T}$ does not affect $I_{m}^{F}$ directly like the foreign exchange variable $\mathrm{X}_{\mathrm{t}-1}$ or the long-term loans variable $\left(\Delta C L_{m}^{\mathrm{L}}\right)$. We should, therefore, examine the mechanism as to how a change in the rate of interest on time deposits ultimately affects private manufacturing investment or total private sector investment positively.

This mechanism is obvious from the specification of our model. We can see from the structural system that an increase in the rate of interest on time deposits, (i.e. $\mathrm{r}^{\mathrm{T}}$ ), initially increases the annual flow of the time deposits into the banks $\left(\Delta D^{T}\right)$. The increase in time deposits is mostly at the cost of currency in circulation with the non-bank public. As time deposits are a component of the total deposits, $\Delta D^{T}$ will affect total deposits $\Delta \mathrm{D}$ according to our identity (4). Since the total deposits variable has a positive direct effect on the commercial loan variable $\left(\Delta \mathrm{CL}_{\mathrm{P}}\right)$, an increase in the rate of interest on time deposits $\left(\mathrm{r}^{\mathrm{T}}\right)$ will increase the supply of commercial loan as well. The change in the loan variable will have effect on the borrowings from the Central Bank by the commercial banks $\left(\triangle R^{B}\right)$ according to our behavioural equation 5. The total annual flow of commercial loan from banks affects the flow of long-term loans from banks positively according to behavioural equation 3. This long-term loan variable affects positively and directly the two private investment variables in our system as an important component of the total flow of long-term loans of all financial institutions. Hence, an increase in the weighted average rate of interest on time deposits will eventually increase the private investment by increasing time deposits and, hence, loanable funds of the banks and loans to the private sector. The quantitative effect on each of the above endogenous variables owing to an initial change in the rate of interest on time deposits can be read from the column of the $\mathrm{r}^{\mathrm{T}}$ variable in the reduced form. These quantitative effects take into consideration the various interactions of the variables and give us the final effects of those interactions which the structural form does not do explicitly.

Before we get on to the three policy variables - Government deficit financing (DF), Government loans from commercial banks $\left(\Delta \mathrm{CL}^{\mathrm{G}}\right)$ and weighted average rate of interest on government securities $\left(\mathrm{r}^{\mathrm{G}}\right)_{-}$, an explanation seems to be in order as to how these three policy instruments could result in an increase in both banks holdings of Government securities (and counter-finance certificates) and bank credit to the private sector. The Government deficit was financed partly by the Central Bank and partly by the commercial banks. The commercial banks' holdings of new issues of Government securities were a result of both persuasion (through raising the rate of interest on Government securities) and compulsion (through considerable influence of the monetary authorities on them). The commercial banks initially financed the increased holdings of Government securities (and counter-finance certificates) partly by some diversion from bank credit but mostly by running down their cash assets below the legal minimum (as evidenced in their negative net free reserves defined as excess reserves minus borrowings from the Central Bank during most of the period under consideration). Having financed the increased holdings of Government securities (and counter-finance certificates) initially that way, the banks would then have an expanded cash base to extend bank credit in all three cases because, firstly, they could reimburse their original cash by borrowing from the Central Bank, using the Government securities as undeniable collaterals, and, secondly, a part of Government deficit spending (financed both by the Central and the commercial banks) would flow back into the commercial banks because the proceeds from the sales of Government securities are not kept as 'idle deposits' by the Government but form an addition to the current income stream of the economy and thus tend to increase the cash base of the banks to extend bank credit. Though an expansion of the cash base by the banks through borrowing from the Central Bank leads to some cost to the banks for the borrowed reserves, (i.e. to the extent the banks are required to maintain required reserves on the basis of borrowed reserves which, however, could be easily passed on to the customers in view of the heavy demand for bank credit), it gives the banks the much-needed loanable funds (which they were originally short of) for expansion of bank credit to the profitable private sector. Hence we see that a rise in the Government deficit expenditure (DF), Government loans from commercial banks $\left(\triangle \mathrm{CL} \mathrm{G}^{\mathrm{G}}\right)$ and weighted average rate of interest on Government securities $\left(\mathrm{r}^{\mathrm{G}}\right)$, would enable banks to expand both the holdings of Government securities (and counter-finance certificates) and bank credit to the private sector by ensuring an increase in their loanable funds. Eventually, in accordance with the structure of our model, this expansion of bank credit by ensuring an increase in the long-term loans from banks to the private sector would affect private investment positively.

Next, we can consider the effect of the weighted average interest rate on Government securities $\left(\mathrm{r}^{\mathrm{G}}\right)$ on the private investment variables. The final effect of a one percent increase in $\mathrm{r}^{\mathrm{G}}$ (rate of interest on Government securities) will increase the total private investment by 49.1 million rupees and the manufacturing invest ment by 18.1 million rupees. As apparent from the structural system, the rate on securities does not affect the private investment variables directly but has direct positive effect on the banks' holdings of securities $(\triangle S)$ according to behavioural equation 6 . Since security holdings of banks (i.e. $\Delta S$ ) are a component of the total 
holdings of securities and counter-finance certificate $\left(\triangle \mathrm{SCL}^{\mathrm{G}}\right)$, this increase in Government security holdings $(\Delta S)$ by banks caused by the rise in the rate of interest on Government securities, will enable the banks to borrow more from the Central Bank by presenting the securities as collateral which the Central Bank is committed to honour. This increased borrowing from the Central Bank will have positive effect on the total commercial loan variable because banks will then have more funds to lend. ${ }^{15}$ Hence a change in the rate of interest on Government securities will affect the commercial loan variable as well. Owing to the interdependence of commercial loan $\left(\Delta \mathrm{CL}_{\mathrm{P}}\right)$ and the borrowing from the Central Bank $\left(\Delta \mathrm{R}^{\mathrm{B}}\right)$ in equations 4 and 5 , the increased lending commitments by banks will lead them to have more borrowings from the Central Bank. The total flow of commercial loans will have a positive effect on the flow of long-term loans from the banks, which, as an important component of the total flow of long-term loans from all financial institutions, will have a direct positive effect on the two private investment variables. Hence, we find that a raising of the weighted rate of interest on Government securities will increase private investment by ensuring an increase in commercial loans by banks. The quantitative effect of the weighted average rate of interest on Government securities on the intermediate financial variables can be read from the relevant column of the $r^{G}$.

We now turn to the effect of the change in the banks' holdings of excess liquid assets (of the previous period). Given the total liquid assets of the banks, the monetary authorities could influence the banks' excess liquid asset holdings by varying the liquid asset ratio which is under their direct control because excess liquid assets are identically equal to the difference between total holdings of liquid assets and the required holdings of it. The final effect of this excess liquid asset (lagged) variable is that a unit increase in it will increase the total private investment and private manufacturing investment by 0.08 and 0.03 million rupees respectively. A unit increase in the flow of excess liquid asset holdings in the previous period will reduce the banks' current-year holdings of Government securities $(\Delta S)$ by 0.24 million rupees (behavioural equation 6) but will result in an increase in the banks' supply of credit to the profitable private sector $\left(\Delta C L_{P}\right)$ by 0.37 million rupees (behavioural equation 4) and that will eventually increase private investment by increasing the long-term loan component of the commercial banks. One interesting point to note is that, according to the behavioural equation 4 , the direct effect of the change in the excess liquid asset holdings (lagged) on the commercial loan is 0.37 but the reduced form suggests that the total effect is slightly greater (i.e. 0.39). The additional indirect effect is due to the appearance of the excess liquid asset variable in this section. the behavioural equation 6 and its effect on the commercial loan variable transmitted therefrom. The mechanism outlined above indicates that the authorities could have affected private investment positively by manipulating the liquid asset ratio. The relevant column of the excess liquid asset variable $\left(\Delta \mathrm{LA}_{-1}^{\mathrm{E}}\right)$ gives the respective quantitative effects on the intermediate and target variable (s).

The next question concerns the effect of Government loans from the commercial banks (i.e. $\Delta \mathrm{CL}^{\mathrm{G}}$ ) and Government deficit financing (i.e. DF). Both these variables have positive effects on investment. Although Government loans from the commercial banks and Government deficit financing do not affect the investment variables directly, the reduced form indicates that they do have a positive (though small) effect on them. A change of a million rupees in Government loans from banks $\left(\triangle C L^{G}\right)$ is associated with changes of 0.31 million rupees and 0.11 million rupees in total private investment and manufacturing investment respectively, whereas the effect of a million rupees change in Government deficit financing (DF) will result in .04 and .02 million rupees change in the above two private investment variables respectively. An increase in the Government loans from the banks enables the commercial banks to increase their borrowings from the Central Bank by producing the counter-finance certificates acquired through lending to the Government. That helps banks to increase their loanable funds and, ultimately, private investment. The Government deficit financing from the banking system results in the acquisition of Government securities (by banks) which are undeniable collateral for borrowing from the Central Bank. The Government deficit financing, therefore, enables banks to increase their borrowings from the Central Bank and thereby their loanable funds in order to affect private investment positively.

Finally, the flow of loans and investments from the specialized credit institutions, being an important component of the total flow of long-term loans, have a positive and direct effect on private investment (both the large-scale and the whole private sectors). Although the Central Bank has no direct overall control on the specialized credit institutions, because the allocation of funds of specialized credit institutions as well as the Government deficit financing operations is determined through joint consultation between the Central Bank and the treasury, the Central Bank, however, can influence (though not control) these important variables and, through them, private investment by exerting its influence on the Government.

It is worth pointing out that there is apparently a paradox in a rise in the rates of interest leading to an increase in private investment. However, this is quite plausible in the context of the period under review. Private investment was insensitive to the rate of interest on private borrowing because the rate of return on investment was well in excess of the controlled market rates of interest. Private investment was 
linked to the availability of funds rather than to the price of the funds. Anything increasing the flow of available funds to the private sector increased private investment. Hence, in accordance with our model, a rise in the weighted average rate of interest on time deposits $\left(\mathrm{r}^{\mathrm{T}}\right)$ and the weighted average rate of interest on Government securities $\left(r^{G}\right)$, which resulted in an increased flow of funds to the private sector, increased private investment. Our findings are consistent with the observations made by Chandler [7], Shaw [25], McKinnon [18], Abe [1], and Fry $[10]$, that in the context of the majority of the under-developed countries, where the effective limitation on investment is not a deficient demand for loan funds but a deficient supply, a rise in the rates of interest vill actually increase real investment to the extent it raises the supply of real savings.

\section{2}

Next we determine which policy variable or which combination of policy variables has the greatest effect on our target variables, viz. the two private investment variables (the one relating to the manufacturing and the other to the whole private sector). As in our previous discussion, we are concerned here mainly with the rows rather than with the columns of the target variable(s).

The rate of interest on time deposit (i.e. $\mathrm{r}^{\mathrm{T}}$ ) seems to have the greatest effect on the private investment. Changes in the rate of interest on Government securities are another important determinant of private investment - the quantitative effects being 30.7 and 18.1 million rupees increases in private manufacturing investment due to a one percent change in the respective rates of interest. In practice, however, only a slight change in the policy variable is possible; hence there may not be a full one percent change in the above rates of interest.

Since the investment in 1969-70 in private large-scale manufacturing and in total private sector was $1,723.4$ million rupees and 4,209.0 million rupees respectively, the effect of a rise of one percent in the weighted rate of interest on time deposits $\left(\mathrm{r}^{\mathrm{T}}\right)$ on the above investment variables would lead to a positive change of 1.7 percent and 1.9 percent respectively and one percent change in the weighted average interest rate on Government securities $\left(\mathrm{r}^{\mathrm{G}}\right)$ would lead to a positive change of 1.0 percent and 1.1 percent respectively. Assuming roughly that private investment was onehalf of the total investment and that investment - G. N.P. ratio was 15 percent and capital-output ratio was 3, a 2 -percent rise in private investment led to about 0.05 percent rise in the growth rate of the G. N.P. That tends to indicate that although the weighted average rates of interest on Government securities and on time deposits were found statistically significant in the banks' holdings of securities and banks' time deposit functions respectively, mainly because these rates of interest helped

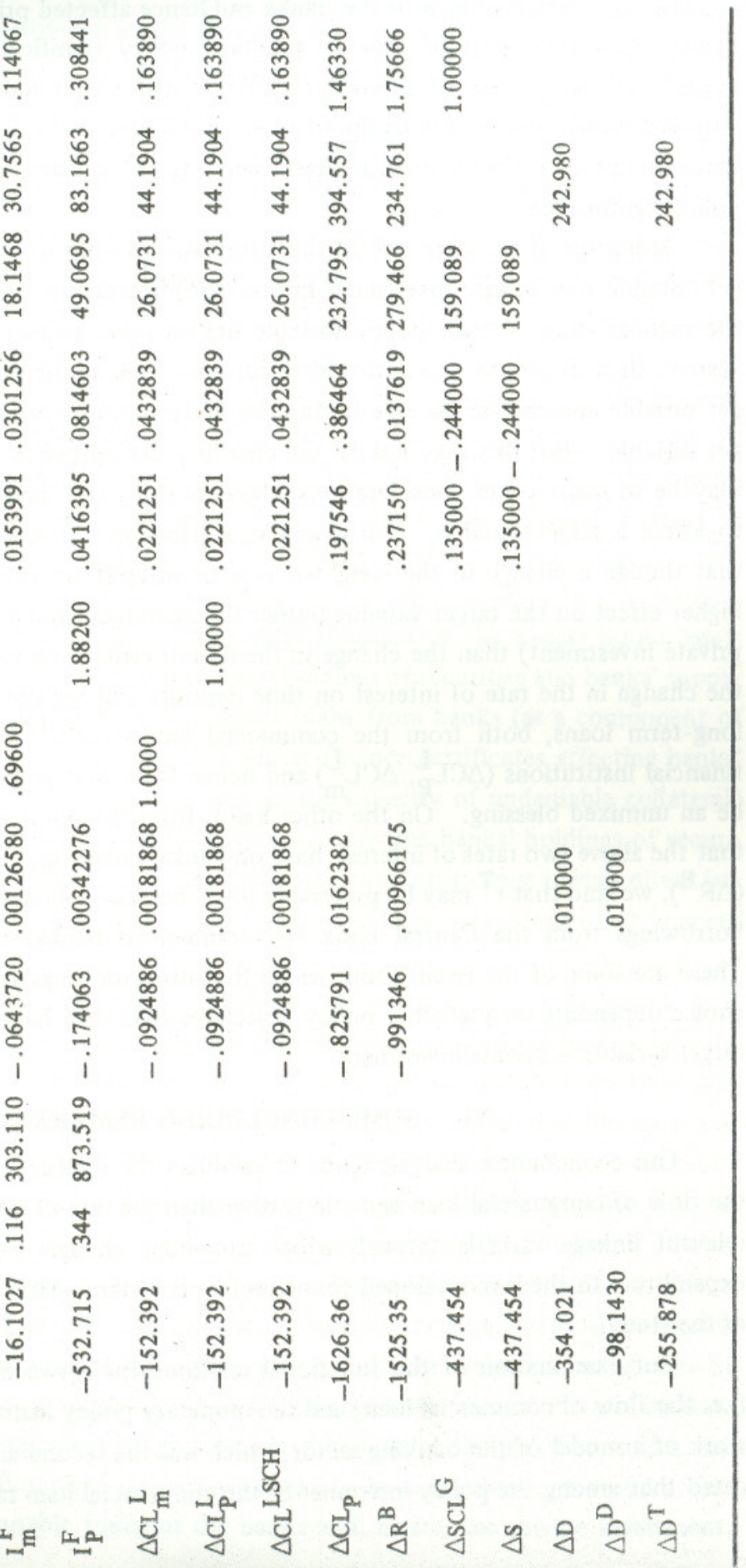


increase the loanable funds of the banks and hence affected private investment positively, from the point of view of practical policy significance, the quantitative impacts of those rates of interest on private investment (and hence on growth), although clearly discernible and positive, do not appear to be significant at all. That tends to indicate that statistical significance might not necessarily mean practical policy significance.

Moreover, if the objective of the authorities is only to maximize a certain target variable (i.e. private investment in our case) irrespective of the side effects that the manipulation of each policy variable has on other endogenous variables of the system, then of course the authorities will only look at the relevant row of the target variable and choose the one having the maximum quantitative effect on the target variable. But this may not be the case in practical policy formulations. There may be so many other considerations when choosing the 'best' policy combination to affect a target variable. For example, a glance at our reduced form will tell us that though a change in the weighted rate of interest on time deposits $\left(\mathrm{r}^{\mathrm{T}}\right)$ has a higher effect on the target variable (either the manufacturing investment or the total private investment) than the change in the rate of interest on Government securities, the change in the rate of interest on time deposits will require much higher flow of long-term loans, both from the commercial banks $\left(\triangle \mathrm{CL}{ }^{\mathrm{LSCH}}\right)$ and from all the financial institutions $\left(\triangle C L_{\mathrm{p}}^{\mathrm{L}}, \Delta \mathrm{CL}_{\mathrm{m}}^{\mathrm{L}}\right)$ and hence from that point of view, $\mathrm{r}^{\mathrm{T}}$ may not be an unmixed blessing. On the other hand, from the point of view of the effects that the above two rates of interest have on banks' borrowing from the Central Bank $\left(\Delta R^{B}\right)$, we find that $r^{T}$ may be preferable to $r^{G}$ because a change in $r^{T}$ will entail less borrowings from the Central Bank (by commercial banks) than a change in $\mathrm{r}^{\mathrm{G}}$. These are some of the issues about which the authorities may have to make a careful choice depending on the other policy objectives that they have apart from the main target variable - private investment.

\section{SOME CONCLUDING REMARKS}

Our econometric analysis tends to establish the significance of, among others, the flow of commercial loan variable (rather than the rate of interest variable) as the relevant linkage variable through which monetary changes make their impact on expenditure in the less developed countries like Pakistan. That fulfilled the first aim of the study.

Our examination of the functional relationships between the linkage variable (i.e. the flow of commercial loan) and the monetary policy instruments in the framework of a model of the banking sector, which was the second aim of the study, indicated that among the policy instruments, the commercial loan rate and the bank rate did not come out significant in the banks' function for bank credit to the private sector and banks' function for borrowing from the Central Bank respectively, since bank credit was mainly supply-constrained and the rise in the cost of borrowing funds could be easily passed on to the customers owing to the high marginal efficiency of capital and, ultimately, to the consumers in the sheltered home market in Pakistan. Nor does the reserve ratio variation (implicit in the excess cash reserve variable) seem to have any significant effect because the raising of the cash reserve ratio meant only higher cost to the banks, which could also be passed on to the customers. Our analysis was inconclusive regarding the efficacy or inefficacy of the selective credit controls and moral suasion, the role of which remains ambiguous in an aggregative macro-economic framework such as ours. All these were on the negative side of the policy instruments. On the positive side, the exercise clearly brings to light the statistical significance of the weighted average rate of interest on Government securities (through its direct effect on banks' holdings of securities), weighted average rate of interest on time deposits (through its direct effect on public's time deposits with banks), the liquidity ratio (implicit in the excess liquid assets variable which have direct bearing on banks' holdings of securities and banks' supply of loans to the private sector), Government loans from banks (as a component of banks' total holdings of securities and counter-finance certificates affecting banks' borrowing from the Central Bank directly in the capacity of undeniable collateral) and Government deficit financing (affecting directly the banks' holdings of securities) and, finally, the loans from the specialized credit institutions having direct impact on private investment (as a component of total long- term loans of all financial institutions).

In summing up, our investigation tends to indicate, among other things, that private investment in Pakistan during the period under review was related directly not to the rates of interest but to the flow of funds because private investment was constrained mainly not by a lack of demand for funds for investment but by a lack of supply of funds. In other words, private investment was linked to the availability of funds rather than to the price of funds since loan rate, like many other rates of interest, was controlled and set far below the equilibrium rate of interest. Our analysis, however, indicates that, though not directly, private investment was affected by some of the interest rates through their effects on the supply of loanable funds and, by implication, on savings. Interest rates such as the weighted average rate of interest on Government securities and the weighted average rate of interest on time deposits were found statistically significant in the banks' holdings of securities and banks' time deposit functions respectively, mainly because these rates of interest helped increase the loanable funds of the banks and, hence, the private investment. 
Although the exercise clearly brings out that even within the existing institutional set-up and the limitations of the monetary policy (especially in the context of a less developed economy like Pakistan's), the individual effects of some of the monetary policy instruments is clearly identifiable and positive on our target investment variable(s), the effect of a unit change of those policy variables on the increase in private investment (and hence on growth) appears to be very limited indeed from the point of view of practical policy significance. This is evidenced in the insignificant increase in private investment (hence in growth) owing to a unit change in those monetary policy instruments as discussed in the previous section. This is a pointer to the fact that the statistical significance of some of the policy instruments might not necessarily lead to a practical policy significance. That tends to indicate that even the indirect effect of the monetary policy instruments on private investment, through their positive effects on the supply of loanable funds, is extremely limited. Our findings of a positive but very limited impact of the monetary policy instruments on private investment and, hence, on growth in the context of a less developed, financially repressed economy like Pakistan's, are, however, quite in accord with the theoretical expectations as expressed in the growing literature cited before. Although the contribution of monetary policy, in the final analysis, can only be judged as a part of the total policy package in association with other policy arms of the Government, such as fiscal and commercial, in the context of which monetary policy might assume relatively greater significance, nevertheless, our study, subject, of course, to its various limitations, tends to cast serious doubt on the efficacy of manipulating only the monetary policy instruments in affecting private investment (and hence growth) of the economy significantly in the economic setting of a less developed country like Pakistan from the point of view of practical policy formulations.

\section{REFERENCES}

1. Abe, S. et al. "Financial Liberalisation and Domestic Saving in Economic Development : An Empirical Test for Six Countries". Pakistan Development Review. Vol. XVI, No. 3. Autumn 1977.

2. Adekunle, J. O. "The Demand for Money : Evidence from Developed and Less Developed Economies". I. M. F. Staff Papers. March 1968.

3. Argy, V. "The Impact of Monetary Policy on Expenditure, with Special Reference to the United Kingdom". I. M. F. Staff Papers. November 1969.

4. Arndt, E. H. D. "Southern Africa". In W. F. Crick (ed.), Commonwealth Banking Systems. Oxford: Clarendon Press. 1965.
5. Avramides, U. "An Econometric Model for Greece with Special Emphasis on the Financial Sector”. Ph. D. Dissertation, University of Leeds. 1972.

6. Chandavarkar, A. G. "Some Aspects of Interest Rate Policies in Less-Developed Economies: The Experience of Selected Asian Countries". I. M. F. Staff Papers. March 1971.

7. Chandler, L. V. Central Banking and Economic Development. Bombay: University of Bombay. 1962.

8. Cohen, J. "Integrating the Real and Financial via the Linkage of Financial Flow”. The Journal of Finance. March 1968.

9. Fan, L. S. and Z. R. Liu. "Demand for Money in Asian Countries; Empirical Evidence". Indian Economic Journal. April-June 1971.

10. Fry, M. J. "Money and Capital or Financial Deepening in Economic Development?" Journal of Money, Credit and Banking. November 1978.

11. Goldfeld, S. M. Commercial Bank Behaviour and Economic Activity. Amsterdam: North Holland. 1966.

12. Gupta, G. S. "A Monetary Policy Model for India". Ph. D. Dissertation, Johns Hopkins University. 1970.

13. Holder, R. F. "Australia". In W. F. Crick (ed.), Commonwealth Banking Systems. Oxford: Clarendon Press. 1965.

14. Imam, H. “A Structural Study of Pakistan's Monetary Sector”. Ph. D. Dissertation, University of Manchester. 1970.

15. Islam, N. A Short Term Model for Pakistan Economy. Karachi: Oxford University Press. 1965.

16. Joshi, M. S. Financial Intermediaries in India. Bombay: University of Bombay. 1965.

17. Madan, B. K. "India". In W. F. Crick (ed.), Commonwealth Banking Systems. Oxford: Clarendon Press. 1965.

18. McKinnon, R. I. Money and Capital in Economic Development. Washington: Brookings. 1973.

19. Mammen, T. “A Test of Friedman's Theory of Demand with Indian Data". Indian Economic Journal. April-June 1971.

20. Masih, A. M. M. "Financial Institutions and Private Investment in Pakistan". Ph. D. Dissertation, University of Leeds. 1974.

21. Niazi, A. U. K. "Some Aspects of Central Banking in Pakistan". Ph. D. Dissertation, Durham University. 1969.

22. Papanek, G. F. "Pakistan's Industrial Entrepreneurs". In W. P. Falcon and G. F. Papanek (eds.), Development Policy II. Cambridge, Mass. (USA): Harvard University Press. 1971. 
23. Porter, R. C. "Narrow Security Markets and Monetary Policy: Lessons from Pakistan". Economic Development and Cultural Change. October 1965.

24. Rajalingam, S. "The Role of Commercial Banks and Specialized Institutions in Financing Economic Development in India, Pakistan and Ceylon". M. Sc. Econ. Dissertation, University of Hull. 1969.

25. Shaw, E. S. Financial Deepening in Economic Development. New York: Oxford University Press. 1973.

26. United Nations. World Economic Survey. New York. 1966. 